\title{
A practical system of bacterial nomenclature
}

\author{
WILLIAM A. BLACK
}

From the Department of Microbiology, University Hospital, London, Ontario, Canada

SYNOPSIS It is unlikely that any serious attempt will be made to standardize bacterial nomenclature on a national or international scale until the implementation of the proposed revision of the International Code of Nomenclature of Bacteria on 1 January 1980. In the meantime, the lack of such standardization poses major problems in communication between the laboratory and the clinician and also causes difficulties in the latter's reading of the bacteriology literature. The present communication proposes interim regional voluntary standardization of bacterial nomenclature as a solution, and outlines a system of nomenclature which could be used on such a regional basis. The system is specifically designed to demonstrate clearly the relationships between bacteria.

Soon after the start of microbiology proficiency testing in Ontario, it became clear that part of the problem in assessing laboratory performance arose from the use of widely differing systems of bacterial taxonomy and nomenclature by the participating laboratories. Not only did adjacent laboratories use varying nomenclature for the same organism, but it was obvious that some laboratories used inconsistent terminology for the same organism on different occasions. A primary concern was the effect of these inconsistencies on the monitoring of microbiology proficiency testing with a computer program, but they would undoubtedly also confuse a clinician receiving reports from several laboratories in the same city. The present system, designed primarily to facilitate data retrieval in proficiency testing programs, is presented as a useful channel for informing both laboratory physicians who issue reports and clinicians who read them of internationally accepted changes in bacterial taxonomy and nomenclature.

\section{The System}

The system is published in a loose-leaf manual comprising a preface, a two-page guide to the system, four pages of contents, 80 pages with approximately 700 coded organisms, and a seven-page index. A copy of the manual was distributed to every laboratory in Ontario under the code name OSIMIB (The Ontario System for the Identification of Medically Important Bacteria).

In compiling the OSIMIB manual, several sources

Received for publication 24 March 1975. were used, including Cowan and Steel's Manual for the Identification of Medical Bacteria (1965) Edwards and Ewing's Identification of Enterobacteriaceae (1972) and the Anaerobic Bacteriolog 9 Manual of Sutter et al (1972). Although the bes\$ features of the nomenclature used in all of the aboye works were freely adopted, the preliminary arrange ment of organisms into sections within the manual was based mainly on the principles used in the new edition of Bergey's Manual of Determinative Bacteriology (1974). In the latter, only those genera which are closely related are grouped into families, and the temptation to create artificial 'families' has been avoided. Organisms which do not fit exactly into a family are grouped together on the basis of morphology, Gram-staining, and growth under aerobic and anaerobic conditions. Using these criteria, the OSIMIB manual is divided into 14 defined sections and a 15th section for organisms of uncertain taxonomic position. Table $\mathrm{I}$, which is from the manual's contents section, illustrates this approach.

The main features in the OSIMIB code are shown in tables II and III. The five-digit code was designed to ensure maximum flexibility. At the species level, $\bar{N}$ the appearance of 1 as the terminal digit denotes what was considered the most appropriate epithet, $\tilde{O}$ for example, 31131 Pseudomonas cepacia. There is no implication that this was always taxonomically the 'correct' term although every effort has been 0 made to ensure that this was so where agreement $\stackrel{\square}{\square}$ was general. Sometimes, however, even the experts $\stackrel{\mathcal{P}}{+}$ disagree, and in these instances, the terminology

${ }^{1}$ A second edition (1974) is now available and was used in minor revisions of OSIMIB. 
Section 1:

GRAM-NEGATIVE AEROBIC BACILLI $\quad \ldots \quad \ldots \quad \ldots \quad \ldots \quad 2$

PSEUDOMONADACEAE (Code 31100)

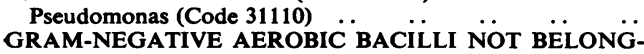

ING TO THE PSEUDOMONADACEAE

Alcaligenes (Code 31510)

Brucella (Code 31610) ...

Bordetella (Code 31710)

Francisella (Code 31810)

Section 2:

GRAM-NEGATIVE FACULTATIVE

$\begin{array}{lllllll}\text { ANAEROBIC BACILLI } & \ldots & \ldots & \ldots & \ldots & \ldots\end{array}$

VIBRIONACEAE (Code 41100)

Vibrio (Code 41110)

Aeromonas (Code 41310)

Plesiomonas (Code 41510)

ENTEROBACTERIACEAE (Code $42100,43100,44100$ )

Escherichia (Code 42110)

Shigella (Code 42310) ..

Edwardsiella (Code 42410)

Salmonella (Code 42510)

Arizona (Code 43110) ..

Citrobacter (Code 43210)

Klebsiella (Code 43310)

Enterobacter (Code 43510)

Serratia (Code 43710)

Pectobacterium (Code 43910)

Proteus (Code 44110) ..

Providencia (Code 44310)

Yersinia (Code 44510) .

GRAM-NEGATIVE FACULTATIVE $\ddot{\text { ANAEROBIC }}$

BACILLI NOT BELONGING TO THE VIBRIONACEAE

OR ENTEROBACTERIACEAE

Pasteurella (Code 45110)

Flavobacterium (Code 45710) ..

Haemophilus (Code 45910) $\ldots$

\begin{tabular}{lllll}
$\ldots$ & $\ldots$ & $\ldots$ & $\ldots$ & 27 \\
$\ldots$ & $\ldots$ & $\ldots$ & $\ldots$ & 28 \\
$\ldots$ & $\ldots$ & $\ldots$ & $\ldots$ & 28 \\
$\ldots$ & $\ldots$ & $\ldots$ & $\ldots$ & 29 \\
\hline
\end{tabular}

Table I An illustrative extract from the contents section of the OSIMIB Manual most widely accepted in Ontario at the present time was used.

\section{Discussion}

The use of OSIMIB as part of a computerized system for data retrieval in microbiology proficiency testing will be discussed elsewhere. From its inception, however, the system was intended also to have a major educational component which is the subject of the present communication.

The need for a system to clarify bacterial nomenclature is obvious. Although the subject has always been controversial, more problems have arisen recently due to growing prominence of Gramnegative bacteria in nosocomial infection and increasing sophistication in the classification of these bacteria. Serratia marcescens, for example, was previously known among other terms as Chromobacterium prodigiosum, and the organism now known as Serratia liquefaciens was previously called Enterobacter liquefaciens and before that Aerobacter subgroup $C$. Again, Ps. cepacia has been known as Ps. multivorans, Ps. kingii or E01. The ultimate in confusion is illustrated by the genus Acinetobacter (table IV) which is the repository for the internationally unacceptable genera Bacterium, Herrellea, and Mima, besides containing two species formerly classified as Moraxella. It is felt that a system like OSIMIB, with a clear presentation of bacterial

\begin{tabular}{|c|c|c|}
\hline Code & Information & Examples \\
\hline 5 digits with a terminal 1 & $\begin{array}{l}\text { a 'Most appropriate'1 species name } \\
\text { b Salmonella serogroup } \\
\text { c Lancefield group of streptococci } \\
\text { d Runyon group of mycobacteria }\end{array}$ & $\begin{array}{l}\text { 43711 Serratia marcescens } \\
42521 \text { Salmonella serogroup B } \\
52121 \text { Lancefield Group A streptococcus } \\
71121 \text { Runyon's Group } 1 \text { mycobacteria }\end{array}$ \\
\hline 4 digits with one terminal zero & Genus & 43710 Serratia, NOS ${ }^{2}$ \\
\hline 3 digits and two terminal zeros & Family & 31100 Pseudomonadaceae \\
\hline 2 digits and three terminal zeros & General descriptive term & $\begin{array}{l}\text { a } 15000 \text { bacilli, Gram-positive } \\
\text { b } 19000 \text { cocci, Gram-positive } \\
\text { c } 23000 \text { spirochaetes }\end{array}$ \\
\hline
\end{tabular}

Table II General principles of the OSIMIB code

'See text under 'The System'

Not otherwise specified

\begin{tabular}{|c|c|c|}
\hline Code & Information & Examples \\
\hline 5 digits with a terminal $1^{1}$ & Most appropriate ${ }^{2}$ species name & 31131 Pseudomonas cepacia \\
\hline 5 digits with terminal digits 2 to 9 & $\begin{array}{l}\text { a Synonyms of the 'most appropriate' } \\
\text { species name } \\
\text { b Strains or sub-types of organisms which } \\
\text { do not have species status }\end{array}$ & $\begin{array}{l}\text { a } 31132 \text { Pseudomonas multivorans } \\
\text { b } 31133 \text { Pseudomonas kingii } \\
\text { c } 31134 \text { EO1 } \\
\text { a } 43312 \text { Friedlander's bacillus } \\
\text { b } 42324 \text { Newcastle bacillus }\end{array}$ \\
\hline Change in the penultimate digit & Change in species & $\begin{array}{l}31111 \text { Pseudomonss aeruginosa } \\
31121 \text { Pseudomonas fluorescens } \\
31131 \text { Pseudomonas cepacia }\end{array}$ \\
\hline
\end{tabular}

Table III Use of the OSIMIB code in demonstrating relationships between bacteria

${ }^{1}$ See Table I for other uses of this coding

'See text under 'The System' 
47710 Acinetobacter, NOS

47711 Acinetobacter calcoaceticus

47712 Acinetobacter anitratus

47713 Bacterium anitratum

47714 Moraxella lwoffii var glucidolytica

47715 Herellea vaginicola

47716 Achromobacter antitratum

47721 Acinetobacter lwoffii

47722 Moraxella lwoffii

47723 Mima polymorpha

Table IV Use of the OSIMIB code with the genus Acinetobacter

synonyms, could be of major importance in aiding medical personnel not only to reconcile reports from different laboratories in any area but also to equate bacterial terminology encountered in the literature with that used by their local laboratories.

In addition, it is anticipated that OSIMIB will facilitate standardization of bacterial nomenclature by diagnostic laboratories in Ontario. Initially, the 300 or so participants in the Ontario Laboratory Proficiency Testing Program will select their choice of synonym for any organism from OSIMIB and then, following publication and distribution of the test results, laboratories using names which are either erroneous, outdated or seldom used elsewhere in the province will be persuaded to adopt a more commonly used OSIMIB synonym. Having reached this point, total standardization can be considered, but the obstacles here will prove formidable until the proposed revision of the International Code of Nomenclature of Bacteria with its Approved Lists of Names of Bacteria is implemented on 1 January 1980. At the present time even reputable taxonomists fail to agree in many cases. Thus, for example, Klebsiella aerogenes, which is the most commonly isolated Klebsiella species in Britain, is one of five species which would be called $K$. pneumoniae in North America. Again, one widely used reference work on the Enterobacteriaceae (Edwards and Ewing, 1972) allocates Arizona to a genus with Arizona hinshawii being the type species; this is unacceptable to both the authors of the 8th edition of Bergey's Manual (1974) and the International Enterobacteriaceae Subcommittee who classify this group of organisms in the genus Salmonella with Salmonella arizonae as the type species. In this atmosphere, the concept of a universally acceptable system of bacterial nomenclature seems utopian even although the International Committee on Systematic Bacteriology is devoted to its accomplishment. Nevertheless, standardization must be attempted in order to permit the collating of reports from different laboratories, and it may well be that a temporary expedient is to standardize nomenclature by the voluntary collaboration of bacteriolo- gists on a regional basis using a system based, as far as possible, on a well-recognized compilation such as Bergey's Manual (1974). Once agreement was reached on the most acceptable terminology, clinicians in the area could be notified of this decision and also of the alternative terminology, so that their own local nomenclature would have a more global perspective.

In Ontario, the use of OSIMIB as a tool in proficiency testing, which in turn is related to laboratory licensing, may in itself stimulate both laboratory and clinically orientated physicians to support standardization of bacterial nomenclature. It is hoped, in addition, that this communication will also stimulate the adoption of similar educative systems in areas which are not engaged in proficiency testing. The use of a system like OSIMIB is not restrictive. It may be thought of as a dictionary of bacterial taxonomy and nomenclature whose acceptance does not imply that one must use, or be immediately familiar with, every word in the text but which will allow one to understand people supposedly speaking the same language; like a dictionary, it will be used less frequently as one becomes more conversant with the language.

I am grateful to Dr Dorothy C. H. Ley for introo ducing me to microbiology proficiency testing in Ontario. The systems implementation of the code was carried out by Mr Shaul Ezer. Dr R. G. E. Murray kindly permitted access to the proofs of the 8th (1974) edition of Bergey's Manual and gave invaluable advice during the preparation of OSIMIB. Dr J. L. Whitby, the other members of the Ontario Laboratory Proficiency Testing Program in Microbiology ${ }^{1}$, and $\mathrm{Mr}$ Brian L. Black reviewed the manuscript. The assistance of Miss Sue Dorse in the proof-reading of OSIMIB was invaluable. This work was in part supported by Ontario Ministry of Health Grant, D.M. 131-'Regional Quality Control Program for Microbiology'.

\section{References}

Buchanan, R. E., and Gibbons, N. E. (Eds.) (1974). Bergey's Manual of Determinative Bacteriology, 8th ed. Williams and Wilkins, Baltimore.

Cowan, S. T. and Steel, K. J. (1965). Manual for the Identification of Medical Bacteria. Cambridge University Press, London.

Edwards, P. R. and Ewing, W. H. (1972). Identification of Enterobacteriaceae, 3rd edition. Burgess, Minneapolis.

Sutter, V. L., Attebery, H. R., Rosenblatt, J. E., Bricknell, K. S., and Finegold, S. M. (1972). Anaerobic Bacteriology Manual. Department of Continuing Education in Health Sciences, University of California, Los Angeles.

${ }^{1}$ Dr S. McDonald, H. Richardson, Dr. H. Sepp, Dr S. Toma, and Dr D. Wood 
Addendum

The new edition of Cowan and Steel employs essentially the same principle as OSIMIB, viz, it chooses what it considers the most acceptable name, admits that this is 'often, but not necessarily, the nomenclaturally correct name', and lists common synonyms so that 'everyone concerned-the bacteriologist, the clinician, and the health official-should all understand what organism is being reported'.

\section{Reports and Bulletins prepared by the Association of Clinical Biochemists}

The following reports and bulletins are published by the Association of Clinical Biochemists. They may be obtained from The Publishing Department, British Medical Journal (ACB Technical Bulletins), B.M.A. House, Tavistock Square, London WC1H 9JR. Overseas readers should remit by British Postal or Money Order.

SCIENTIFIC REPORTS (price $£ 1.00 / \$ 2.00$ each)

3 Automatic Dispensing Pipettes: an assessment of 35 commercial instruments September 1967 P. M. G. BROUGHTON, A. H. GOWENLOCK, G. M. WIDDOWSON, and K. A. AHLQUIST

4 An Evaluation of five Commercial Flame Photometers suitable for the Simultaneous Determination of Sodium and Potassium March 1970 P. M. G. BROUGHTON and J. B. DAWSON

SCIENTIFIC REVIEWS (price $£ 1 \cdot 00 / \$ 2.00$ each)

1 The Assessment of Thyroid Function March 1971 F. V. FLYNN and J. R. HOBBS

2 Renal Function Tests Suitable for Clinical Practice January 1972 F. L. MTCHELL, N. VEALL, and R. W. E. WATTS

3 Biochemical Tests for the Assessment of Fetoplacental Function May 1975 C. E. WILDE and R. E. OAKEY

TECHNICAL BULLETINS (price $£ 1 \cdot 00 / \$ 2.00$ each)

9 Determination of Urea by AutoAnalyzer November 1966 RUTH M. HASLAM

11 Determination of Serum Albumin by AutoAnalyzer using Bromocresol Green October 1967 B.E. NORTHAM and G. M. WIDDowson

13 An Assessment of the Technicon Type II Sampler Unit March 1968 B. C. GRAY and G. K. MCGOWAN

14 Atomic Absorption Spectroscopy: an outline of its principles and a guide to the selection of instruments May 1968 J. B. DAWSON and P. M. G. BROUGHTON

15 A Guide to Automatic Pipettes (2nd edition) June 1968 P. M. G. BROUGHTON

16 A Guide to Automation in Clinical Chemistry May 1969 P. M. G. BROUGHTON

17 Flame Photometers: a comparative list of 17 instruments readily available in Britain August 1969 P. WILDING

19 Spectrophotometers: a comparative list of low-priced instruments readily available in Britain May 1970 C. E. WILDE and P. SEWELL
20 Quantities and Units in Clinical Biochemistry June 1970 P. M. G. BROUGHTON

21 Filter Fluorimeters: A comparative list of 18 instruments September 1970 H. BRAUNSBERG and $s$. $s$. BROWN

22 Bilirubin Standards and the Determination of Bilirubin by Manual and Technicon AutoAnalyzer Methods January 1971 BARBARA BILLING, RUTH HASLAM, and N. WALD

23 Interchangeable Cells for Spectrophotometers and Fluorimeters September 1971 s. S. BROWN and A. H. GOWENLOCK

24 Simple Tests to Detect Poisons March 1972 B. w. MEADE et al.

25 Blood Gas Analysers May 1972 K. DIXON

26 Kits for Enzyme Activity Determination September 1972 S. B. ROSALKI and D. TARLOW

27 Assessment of Pumps Suitable for Incorporation into Existing Continuous Flow Analytical Systems November 1972 A. FLECK et al.

28 Routine Clinical Measurements of Transferrin in Human Serum September 1973 K. DIXON

29 Control Materials for Clinical Biochemistry (5th edition) September 1973 J. F. STEVENS

30 Notes on the Quality of Performance of Serum Cholesterol Assays September 1973 s. S. BROWN

31 Determination of Uric Acid in Blood and in Urine July 1974 R. W. E. WATTS

32 A Survey of Amino Acid Analysers Readily Available in the United Kingdom September 1974 J. E. CARLYLE and P. PURKISS

33 Definitions of some Words and Terms used in Automated Analysis November 1974 A. FLECK, R. ROBINSON, S. S. BROWN, and J. R. HOBBS

34 Measurement of Albumin in the Sera of Patients January 1975 LINDA SLATER, P. M. CARTER, and J. R. HOBBS

35 Investigation of the Validity of Temperature Correction Factors for Serum Aspartate and Alanine Transaminases March 1975 s. B. ROSALKI et al. 